\title{
Paleoseismic study on active normal faults in the southeastern Weihe Graben, central China
}

AUTHOR(S):

Rao, Gang; Lin, Aiming; Yan, Bing

\section{CITATION:}

Rao, Gang ... [et al]. Paleoseismic study on active normal faults in the southeastern Weihe Graben, central China. Journal of Asian Earth Sciences 2015, 114(Part 1): 212-225

\section{ISSUE DATE:}

2015-12

URL:

http://hdl.handle.net/2433/204522

\section{RIGHT:}

(c) 2015. This manuscript version is made available under the CC-BY-NC-ND 4.0 license

http://creativecommons.org/licenses/by-nc-nd/4.0/; The full-text file will be made open to the public on 1 December 2017 in accordance with publisher's 'Terms and Conditions for Self-Archiving'., この論文は出版社版でありません。引 用の際には出版社版をご磼認ご利用ください。; This is not the published version. Please cite only the published version. 


\title{
Paleoseismic study on active normal faults in the
}

\section{southeastern Weihe Graben, central China}

\author{
Gang Rao ${ }^{1,2}$, Aiming Lin ${ }^{1, *}$, Bing Yan ${ }^{1,3}$ \\ ${ }^{1}$ Department of Geophysics, Graduate School of Science, Kyoto University, \\ Kyoto 606-8502, Japan \\ ${ }^{2}$ Department of Earth Sciences, Zhejiang University, \\ Hangzhou 310027, China \\ ${ }^{3}$ School of Earth Sciences and Engineering, Nanjing University, \\ Nanjing 210093, China
}

\section{*Corresponding author:}

Department of Geophysics

Graduate School of Science, Kyoto University

Kyoto 606-8502, Japan

Tel.: 81-75-753-3941

E-mail: slin@kugi.kyoto-u.ac.jp (A. Lin) 


\section{Abstract}

Field investigations and trench excavations can provide direct and indirect

geological evidence for the occurrence of paleo-earthquakes. In this study, we present geological and topographical evidence for the occurrence of great paleo-earthquakes produced by active normal faults in the southeastern Weihe Graben, central China. Field and trench observations, in combination with radiocarbon ages, reveal that: i) four surface-faulting events occurred in the past 4000 years with an average recurrence interval of $\sim 1000$ years, which is in contrast with the previously estimated interval of $\sim 2000-2900$ years; ii) the most recent fault event is correlated to the 1556 $\mathrm{M} \sim 8.5$ Huaxian earthquake; iii) an alluvial terrace riser that formed at $\sim 5300 \mathrm{yr}$ B.P. has been vertically offset by $9-11 \mathrm{~m}$, indicating an average vertical slip rate of $1.7-2.1$ $\mathrm{mm} / \mathrm{yr}$ in the late Holocene. Our results confirm that normal faults in the southeastern Weihe Graben have been active in the late Holocene as source seismogenic faults, and that these faults have the potential to trigger large earthquakes of $M>7$ in the future. Therefore, it is important to urgently reevaluate the seismic potential and seismic hazard in the densely populated Weihe Graben region.

Keywords: normal fault, great paleo-earthquake, 1556 M 8.5 Huaxian earthquake, recurrence interval, Weihe Graben, Ordos Block

\section{Introduction}

Investigations on the seismogenic behavior of active faults, especially during the 
Holocene, are important for assessing the seismic hazard in regions with high historical seismicity (e.g., Yeats et al., 1997; Meghraoui et al., 2001; Lin and Guo, 2008; De Pascale and Langridge, 2012). However, geological evidence of paleoseismicity and precise age constraints for past earthquakes are generally lacking, except for limited recordings of human casualties and damage to infrastructure in areas with ancient historical documents, such as China (e.g., CENC, 2007; Lin et al., 2013a). In central China, near the city of Xi'an (an ancient capital on the loess plateau), an earthquake with a large magnitude of $\sim 8.5$ (the Huaxian great earthquake) occurred on January 23, 1556 and caused more than 830,000 deaths, making this earthquake the most deadly in history (Kuo, 1957; SSB, 1988; Xie, 1992; CENC, 2007). In the epicentral area between Weinan and Huayin (Fig. 1c), local residents have for thousands of years lived in loess cave dwellings that are susceptible to collapse during earthquakes, and this might explain the great number of deaths. Although the tectonic activity and structural features of active faults in the epicentral area of the Huaxian great earthquake have been reported previously (e.g., Li and Ran, 1983; SSB, 1988; Zhang et al., 1995; Hou et al., 1998; Yuan and Feng, 2010; Rao et al., 2014), the seismogenic behavior of associated faults remains unclear. Based on field observations of fault scarps and outcrops, previous studies have inferred that the Huashan Piedmont Fault (HPF in Fig. 1c) was the seismogenic fault of the 1556 event (e.g., SSB, 1988; Zhang et al., 1995). However, the paleoseismology of the Northern Margin Fault of the Weinan Loess Tableland (NMF-WLT in Fig. 1c), another important active normal fault located between 
Weinan and Huaxian in the southeastern Weihe Graben, remains unknown even though it has been active during the late Pleistocene-Holocene (e.g., Yuan and Feng, 2010; Rao et al., 2014).

In this study, we present a paleo-seismological study on the NMF-WLT and calculate the slip-rate, recurrence interval, and timing of recent faulting events. Then, we discuss the implications of our findings for seismic hazard assessment in the densely populated Weihe Graben region.

\section{Geological setting}

The Cenozoic intracontinental Weihe Graben is located along the southern margin of the Ordos Block, which is composed mainly of pre-Mesozoic crystalline basement (Ma and Wu, 1987; SSB, 1988). To the south, the graben is bounded by the Qinling Mountains, which were formed in response to the collision between the North China Block (NCB) and South China Block (SCB) in the Triassic (Fig. 1a; Meng and Zhang, 2000; Rastchbacher et al., 2003). Long-term extension since the Eocene ( $50 \mathrm{Ma})$ has caused subsidence, resulting in thick $(>7 \mathrm{~km})$ graben sedimentary fill, and the uplift of blocks including the Huashan Mountains and Weinan Loess Tableland (SSB, 1988,

Zhang et al., 1998). The Huashan Mountains are composed primarily of pre-Mesozoic metamorphic basement, in contrast to the late Quaternary loess and alluvial sediments of the Weinan Loess Tableland (Fig. 1c). Fission-track dates reveal that uplift of the Huashan Mountains started at $\sim 68.2 \mathrm{Ma}$ and accelerated with an average uplift rate of $\sim 0.19 \mathrm{~mm} / \mathrm{yr}$ since $\sim 17.8 \mathrm{Ma}$ (Yin et al., 2001). In contrast, major uplift of the Weinan 
Loess Tableland occurred after 1.2 Ma (Feng and Dai, 2004). Previous studies have demonstrated that active faults along the northern margins of these uplifted belts are characterized by stepped scarps and dominated by normal slip; the average vertical slip rate on the faults is $\sim 2-3 \mathrm{~mm} / \mathrm{yr}$ for the late Pleistocene to Holocene (e.g., Li and Ran, 1983; SSB, 1988; Deng et al., 2003; Rao et al., 2014). The development of active normal faults in the Weihe Graben is considered to be related to the pre-existing spreading and rifting of the continental crust due to the variations in lithospheric structures relative to the neighboring Ordos Block and Qinling Mountains (SSB, 1988; Bao et al., 2011; Rao et al., 2014; Lin et al., 2015).

The study area, the southeastern Weihe Graben, has a long historical record of earthquakes dating back more than 2000 years to 780 BC (SEIN, 2011). At least seven $\mathrm{M}>6$ earthquakes have been recorded (Table 1). In the case of the $1556 \mathrm{M} \sim 8.5$ Huaxian great earthquake, it has been suggested that an active fault zone ruptured along a distance of up to $70 \mathrm{~km}$ in the southeastern marginal zone of the Weihe Graben (e.g., Wang, 1980; Xie, 1992; CENC, 2007). Historical documents and previous investigations reveal the epicenter was located between the modern cities of Weinan and Huayin; its intensity was XII, the maximum magnitude measured on the China Seismic Intensity Scale (Fig. 1c; Kuo, 1957; Xie, 1992; CENC, 2007; Deng, 2007; Yuan and Feng, 2010).

\section{Study methods}

We integrated high-resolution, remote sensing imagery with field work to 
109

110

investigate the tectonic landforms and structural features related to paleoseismicity along the NMF-WLT (Locs. 1-4; Fig. 1c). We also excavated two trenches on distinct fault scarps_along the northern margin of the Weinan Loess Tableland (Locs. 5 and 6 in Fig. 1c). Fault-related structures exposed on trench walls were used to identify fault events. To precisely bracket the timing of fault events, radiocarbon dating of organic-rich trench samples was performed by accelerator mass spectrometry (AMS) at the Institute of Accelerator Analysis Ltd., Japan and at BETA Analysis Inc., USA (Table 2).

\section{Outcrop observations}

Fault outcrops at Locations 1 and 2 occur on both banks of the Chishuihe River, along an active fault trace at the northern margin of the Weinan Loess Tableland (Fig. 2b). The fault is characterized by fault scarps developed on terrace and loess plateau surfaces (Fig. 2a and b). The T1 terrace is vertically offset by $\sim 10 \mathrm{~m}$ across the fault (Fig. 2c). Alluvial deposits of the T1 terrace containing organic soil yield a radiocarbon age of $\sim 5,300 \mathrm{yr}$ B.P. (see Fig. $2 \mathrm{~b}$ for the sample site). The fault plane at Locations 1 and 2 strikes $\mathrm{N} 40^{\circ} \mathrm{W}$ and dips $55^{\circ}$ to the northeast (Fig. 3a-c). Striations on the fault plane indicate normal slip, consistent with the T1 terrace scarp (Fig. 3d and e).

Along the western segment of the NMF-WLT, approximately 5-10 km from Location 2, two fault outcrops occur where the fault branches into two to three sub-faults (Locs. 3 and 4; Fig. 4a). The fault cuts alluvial terraces of the Weihe River 
131

132

and its tributary alluvial fans with a maximum vertical offset of $\sim 4.6 \mathrm{~m}$ (Fig. 4b).

We observed a $\sim 0.5-0.7-\mathrm{m}$-wide vertical ground fracture in loess deposits along the scarp at Location 3 (Fig. 4c). Striations on the fracture sidewall indicate normal slip (Fig. 4d and e). Radiocarbon dating of an organic soil that fills the fracture yields an age of $\sim 3,920$ yr B.P., which is younger than that of the host loess deposit $(\sim 22,480$ to $\sim 16,270$ yr B.P.) (Fig. 4c; Table 2). Therefore, we infer that the ground fracture developed around 3,920 yr B.P.

At Location 4, 1 km south of the Weihe River, a 10-m-high fault scarp, striking NW and extending for $>1 \mathrm{~km}$ (Fig. 4a), cuts the river's lowest terrace (Fig. 5a-c). The terrace is composed of yellow-brown sandy loess intercalated with sandy silt, and these beds have been deformed into broad folds (Fig. $5 \mathrm{c}-\mathrm{e}$ ). In the axis of one syncline, sand-silt layers have been liquefied (Fig. 6). The liquefied sand-silt deposits show an irregular zoning structure including silt-sand, sand, and sand-gravel zones (Fig. 6b, c). Grain size analysis places the sands in a range of $0.1-1.0 \mathrm{~mm}$, known to be prone to liquefaction during seismic ground shaking (e.g., Lin, 1997; Obermeier and Dickenson, 2000), Therefore, we suggest that the irregular zoning structure of liquefied deposits may be formed by multiple strong earthquakes because the liquefied sand-silt deposits would be disturbed and mixed by a large earthquake due to strong ground motion.

Organic soil and calcium carbonate shells from the liquefied beds yield ${ }^{14} \mathrm{C}$ ages ranging from $\sim 36,080$ to $\sim 6,360$ yr B.P. (Fig. 6c; Table 2). Combining with the distribution features of grain size, and zoning structures of liquefied silt-sand deposits, 
153

154

155

156

157

158

159

160

161

162

163

164

165

166

167

the broad ${ }^{14} \mathrm{C}$ ages probably indicate multiple strong earthquakes associated with liquefaction that occurred at this site. Therefore, we suggest the recent seismic

faulting event that caused liquefaction occurred after $\sim 6,360$ yr B.P. (Fig. 6c; Table 2).

\section{Trench investigations}

\subsection{Trench A}

Trench A (Loc. 5; Fig. 4a) was excavated across a fault scarp that cuts several small alluvial fans (Fig. 7a). Along the scarp, we measured vertical offsets of $\sim 1.6$ and $0.5 \mathrm{~m}$ on older and younger fans, respectively (Fig. 7a and b). We also observed a ground fracture with a strike of $\mathrm{N} 60^{\circ} \mathrm{E}$ and normal-slip striations on its sidewall (Fig. $7 \mathrm{c}$ and $\mathrm{d})$, indicating its development along the main fault plane.

To verify the nature of faulting, a trench $\sim 8 \mathrm{~m}$ long and $\sim 4 \mathrm{~m}$ deep was excavated at Location 5 (Figs. 8-10). Stratigraphic units (1-8) exposed on the east wall of the trench are composed of surface soil, loess deposits, and silt-sand beds with complex injection veins, as well as colluvium (Figs. 8 and 10). The F1 fault offsets the strata and is itself cut by an injection vein filled with irregular fragments of loess and soil (Figs. 8 and 10b), an indication that repeated seismic events occurred in this location. The west wall of the trench contains silt-sand beds and colluvium cut by multi-stage injection veins filled with unconsolidated silt-soil matrix and rounded to angular fragments of loess and soil which range from a few millimeters to $10 \mathrm{~cm}$ in diameters, showing different colors with the neighboring sediments (Fig. 9). Locally, the injection veins are branched into many veinlets and complex networks (Figs 9 and 
175

176

177

10). Three faults (F1-F3) are identified based on deformed and offset stratigraphic units: the F1 and F2 faults cut Units 6 and 7, and the F3 fault cuts Units 2 and 8-11 (Fig. 9b). The strata contain numerous shells and organic-rich soil yielding radiocarbon ages of $>43,500$ to $\sim 7,670 \mathrm{yr}$ B.P. (Fig. $9 \mathrm{~b}$; Table 2). In contrast, radiocarbon ages of near-surface Units 2 and 3 are older than those of the underlying sediments (samples C02 and C14; Fig. 9b); we suggest this inversion of sedimentary units was caused by the collapse of over-steepened fault scarps.

\subsection{Trench B}

Trench B was excavated across a 1.6-m-high fault scarp along the north margin of the loess plateau near the Weihe River (Fig. 11; see Fig. 4a for the location).

Stratigraphic units exposed in the trench are yellow-gray sandy silt, gray silty soil, yellow sandy loess, and dark gray surface soils containing abundant organic-rich soil suitable for radiocarbon dating (Figs. 11 and 12). On the west wall of the trench, six faults (F1-F6) are identified; faults F4-F6 cut older stratigraphic units (Units 13-19), whereas faults F1-F3 faults cut younger strata (Units 1-11) (Fig. 12). A sand-soil vein is injected along the F5 fault plane (Fig. 12b). In contrast with the flat-lying Units 1-10, Units 11-19 are deformed and steeply tilted. Radiocarbon ages for Units 14 and 16 are 19,358 and 30,807 yr B.P., respectively; Unit 5 (an injection vein) yields a radiocarbon age of 2,921 yr B.P. (Fig. 12b; Table 2). In contrast, surface soil Units 3, 5 and 8 are younger at 676-2,590 yr. B.P. (Fig. 12b; Table 2). 
197

198

199

200

201

202

203

204

205

206

207

208

209

210

211

212

213

214

215

216

217

218

\subsection{Identification of seismic faulting events}

In Trench A, deformed and/or disturbed beds, offset strata, fissure-filled veins, and scarp-collapse deposits were used to identify paleo-seismic faulting events. On the east wall of the trench, the F1 fault offsets Units 2-7, an indication that the associated earthquake occurred after their deposition. The F1 fault plane was later displaced during the seismically induced injection of colluvium which consist of sand-silt fragments varying in diameters and different colors with the neighboring sediments (Figs. 8 and 10a). Therefore, the east wall contains evidence of at least two paleoearthquakes.

Widely distributed gray injection veins in sedimentary Units 2, 4, 7 and 8 are also indicative of seismic events (Figs. 8 and 10c); similar structures, triggered by paleo-earthquakes on pre-existing active faults, have been reported recently (e.g., Lin et al., 2013b, 2014, 2015).

On the west wall, the F1 fault cuts Units 5 and 6 and is overlain by Unit 4;

therefore, a seismic faulting event occurred after the formation of Unit 6, but prior to that of Unit 4, between $\sim 42,130$ and $\sim 22,280$ yr B.P. (Fig. 9b; Table 2). The F2 and F3 faults and their sub-faults cut Units 7 and 8, indicating a faulting event occurred after the deposition of Unit 8 (7,670-23,170 yr B.P.; Fig. 9b; Table 2).

In Trench B, at least six seismic events can be identified, five of which occurred in the late Holocene. On the west wall, the F5 and F6 faults cut Units 14-18, indicating that at least one seismic faulting event occurred after the formation of Unit 14, between 30,807 and 19,358 yr B.P. (Fig. 12b; Table 2). The presence of a surface 
219

220

222

223

224

soil vein (Unit 15) injected into Unit 14 indicates that another faulting event (Ea1) occurred after the injection of Unit 15 at 2,921 yr B.P. (Fig. 12b; Table 2).

As shown in Fig. 12, younger sedimentary units (Units 1-10) are sharply fault-bounded with older sedimentary units (11-19). Unit 10 is steeply $\left(64^{\circ}\right)$ bounded by the F2 fault, cut by the F1 fault, and overlain by a brown-gray surface soil (Unit 8). We suggest the following sequence of events following the development of fault F2: i) a fault event (Eb1) occurred along the high-angle scarp, prompting scarp collapse and the deposition of Unit 10; ii) a fault event (Eb2) occurred just prior to the deposition of Unit 8 at 2,590 yr B.P. (Fig. 12b; Table 2); iii) a fault event (Eb3) occurred along fault F2 that bounds Units 6 and 7, after the deposition of Unit 8 and prior to the deposition of Unit 5 (Fig. 12b; Table 2); and iv) a fault event (Eb4) that occurred after the deposition of Unit 2 (676 \pm 23 yr B.P.; Fig. 12b; Table 2). Three surface soil layers (Units 3, 5, and 8), which are sedimentary markers of seismic activity, were formed after individual faulting events, yielding an average recurrence interval of $\sim 1000$ years.

Previous studies show that there is a general tendency that strong to large earthquakes in extensional regime usually ruptured on one or some of the fault segments of the associated active faults (McCalpin, 2009). It is possible that some events occurred at one site and not at the other due to discontinuous distribution of coseismic displacement and complicated geometry of faults. In this study, we also found that there is no similar seismic event identified from different sites. This discrepancy may also reflect hiatuses in deposition due to small vertical offsets and 
241

242

ground subsidence during the paleoseismic events. Therefore, to precisely bracket the timing of fault events, multiple trench sites are usually chosen to make the comparison of paleo-earthquakes identified from each sites.

In summary, trench investigations reveal that four surface faulting events occurred in the past $\sim 4000$ years, with a recurrence interval of $\sim 1000$ years.

\section{Discussion and conclusions}

\subsection{Recurrence interval of normal-slip earthquakes}

We calculated the recurrence interval of successive late Holocene earthquakes based on topographic relationships, deformation features, and ${ }^{14} \mathrm{C}$ ages along active normal faults in the study area. Topographic profiles show that the $\mathrm{T} 1$ terrace $(5,300$ yr B.P.) has a vertical offset of $\sim 10 \mathrm{~m}$ (Fig. 2b). Previous work has shown that the 1556 M 8.5 Huaxian great earthquake caused an average vertical offset of $\sim 2-3 \mathrm{~m}$ (SSB, 1988). If we use $2-3 \mathrm{~m}$ as a characteristic offset for individual great earthquakes in this area, then a total offset of $10 \mathrm{~m}$ is inferred to be the sum result of three to five large earthquakes over the past $\sim 5,000$ years. Liquefaction of alluvial sand and silt at Location 4 also indicates that at least one faulting event occurred in the past $\sim 6,300$ years (Fig. 6).

Multiple late Pleistocene ( 20,000-45,000 yr B.P.) and one Holocene $(<7,670 \mathrm{yr}$ B.P.) faulting events are identified in Trench A (Fig. 9b). However, in Trench B we identify four surface faulting events over the past $\sim 4000$ years, with a recurrence 
263

264

interval of $\sim 1000$ years. The Ea1 event occurred at $\sim 2,921 \mathrm{yr}$ B.P. based on the age of a surface soil vein injected into Unit 14 (Fig. 12b). The Eb1 event occurred just prior to the formation of Unit 10. Using an average recurrence interval of $\sim 1000$ years over the past 3,000 years, we infer that the Eb1 event occurred at $\sim 4,000$ yr B.P. We also infer that the Eb2 event occurred before the formation of Unit $8(\sim 2,590 \mathrm{yr}$ B.P. $)$ and may correspond to the Eal event that occurred at 2,921 yr B.P. (Fig. 12b; Table 2). The Eb3 event occurred between 1,145 and 2,590 yr B.P., which are the ages of Units 8 and 5, respectively. The Eb4 event is inferred to be the most recent event, occurring in the past 676 years (1360-1388 AD).

Historical documents record seven large $M \geq 6$ earthquakes in the Weihe Graben over the past $\sim 3,000$ years, including the $1556 \mathrm{M} \sim 8.5$ Huaxian great earthquake and two large earthquakes of $\mathrm{M} \geq 7$ (1501 $\mathrm{AD}$ and $780 \mathrm{BC}$; Table 1). However, previous work showed that surface rupturing in the graben systems around the Ordos Block is generally related to $\mathrm{M}>7$ earthquakes (SSB, 1988). For example, the 1996 M6.4 Baotou earthquake did not produce a surface rupture in the Hetao Graben (Li, 2005). Based on historical records, the epicenter of the $1501 \mathrm{M} \sim 7$ Chaoyi earthquake was near Dali city in the eastern Weihe Graben (SEIN, 2011). Recent study shows that the 1501 Chaoyi earthquake probably occurred in the Shanxi Graben, northeast of the Weihe Graben (Lv et al., 2014). Consequently, only two large historical earthquakes (i.e., the $\mathrm{M} \sim 7780 \mathrm{BC}$ Qishan and $\mathrm{M} \sim 8.51556$ Huaxian great earthquakes) are associated with active faults in the Weihe Graben. 
285

286

287

to the $\mathrm{M} \sim 8.51556$ Huaxian great earthquake. The Eb3 event occurred between 1,145 and 2,590 yr B.P. Considering the range of ${ }^{14} \mathrm{C}$ dating errors, the $\mathrm{Eb} 3$ event might be correlated with the $793 \mathrm{AD}$ earthquake of $\mathrm{M} \sim 6.5$. The magnitude of historical earthquake is generally estimated from the seismic intensity that is inferred from the historical record. The magnitude (M 6.5) of the $793 \mathrm{AD}$ earthquake may be underestimated due to the lack of historical documents recorded one thousand years ago. To better understand this event, more work is needed. The Eb2 event occurred between 2,591 and 2,921 yr B.P. and may be related to the M 7 $780 \mathrm{BC}$ earthquake. The demonstrated seismic faulting events including the Eb4, Eb3, and Eb2 are mostly in agreement with the historical documents recorded since 780 BC (Table 1). Since the 1556 earthquake, no strong earthquake has occurred in the study area. Many active faults are distributed throughout regions neighboring the study area, with similar potential to trigger large earthquakes and significant ground deformation (Lin et al., 2015, this issue). Therefore, more work is required to better understand the recurrence interval of large earthquakes and their deformation characteristics, and thereby improve ongoing assessments of seismic hazards in the densely populated Weihe Graben region.

\subsection{Rate of normal slip}

Although previous studies have described fault outcrops along the NMF-WLT (e.g., Yuan and Feng, 2010; Rao et al., 2014), the rate of fault slip remains poorly constrained, making it difficult to assess the potential seismic hazard. Here, we use 
307

308

309

310

311

312

313

topographic analysis of displaced terraces and ${ }^{14} \mathrm{C}$ ages to calculate an accumulated vertical offset of $\sim 9-11 \mathrm{~m}$ on the T1 terrace since $\sim 5,300 \mathrm{yr}$ B.P. (Fig. 2; Table 2).

Striations on the main fault plane indicate nearly pure normal slip (Fig. 3). Therefore, we estimate the average rate of fault slip on the NMF-WLT to be $\sim 1.7-2.1 \mathrm{~mm} / \mathrm{yr}$ during the Holocene. This result is consistent with a previous estimate for late Pleistocene slip of $\sim 2-3 \mathrm{~mm} / \mathrm{yr}$ for the epicenter of the 1556 Huaxian great earthquake (e.g., Li and Ran, 1983; Deng et al., 2003; Rao et al., 2014) and also agrees with a slip estimate of $\sim 0.5-1.1 \mathrm{~mm} / \mathrm{yr}$ for active normal faults in the northwestern Weihe Graben (Lin et al. 2015, this issue). Coupling an average slip rate of $\sim 2 \mathrm{~mm} / \mathrm{yr}$ with a single-event offset of $\sim 2 \mathrm{~m}$ (characteristic of M7-8 earthquakes in the study area), the recurrence interval of M7-8 earthquakes is $~ 1000$ years, consistent with the recurrence interval estimated from trench investigations.

\section{Acknowledgements}

We thank the Earth Remote Sensing Data Analysis Center (ERSDAC) for making ASTER GDEM data freely available. We are grateful to Profs. D. Jia and J. Hu, and Drs. Z. Ren, X. Wu, J. Fu, J. Du, H. Chen, and W. Gong for discussions and help in the field. Thanks also due to Prof. H. Li and Dr. Z. Wang for their valuable critical reviews that greatly improved the manuscript. This work was supported by the Science Project (23253002) from the Ministry of Education, Culture, Sports, Science and Technology of Japan and partially by the Fundamental Research Funds for the Central Universities (No. 2014QNA3010). 


\section{References}

CENC (China Earthquake Network Center), 2007, The 1556 Huaxian great earthquake, Shaanxi, China: the largest total of fatalities ever claimed (in Chinese). Available online at: http://www.csi.ac.cn/manage/html/4028861611c5c2ba0111c5c558b00001/_histor y/hxz/qyzhenhai/zh20060609002.htm (Last accessed, 30 August 2014)

Deng, Q., Zhang, P., Ran, Y., Yang, X., Min, W., Chu, Q., 2003. Basic characteristics of active tectonics of China. Sci. China Ser. D 46, 356-372.

Deng, Q., 2007. Active Tectonics Map of China, Seismological Press (in Chinese).

De Pascale, G., Langridge, R., 2012. New on-fault evidence for a great earthquake in A.D. 1717, central Alpine fault, New Zealand. Geology 40, 791-794.

Feng, X., Dai, W., 2004. Lateral migration of fault activity in Weihe basin. Acta Seismologica Sinica 17, 190-199.

Geological Bureau of Shaanxi Province (GBSP), 1999. Regional Geology of Shaanxi Province, China Geological Survey, Beijing.

Hou, J., Han, M., Chai, B., Han, H., 1998. Geomorphological observations of active faults in the epicentral region of the Huaxian large earthquake in 1556 in Shaanxi Province, China. J. Struct. Geol. 20, 549-557.

Kuo, T., 1957. On the Shensi earthquake of January 23, 1556. Acta Geophysica Sinica, 6, 59-68 (in Chinese with English abstract).

Li, J., 2005. Research on the satellite remote sensing images indicative of strong earthquake preparation in the Ordos north marginal fault basin region. 
Li, X., Ran, Y., 1983. Active faults along the north margins of Huashan and Weinan

Lin, A., 1997. Instantaneous-shaking liquefaction induced by the M7.2 1995 Southern Hyogo Prefecture earthquake, Japan. Geology 25, 435-438.

Lin, A., Yamashita, K., Tanaka, M., 2013b. Repeated seismic slips recorded in ultracataclastic veins along active faults of the Arima-Takatsuki Tectonic Line, southwest Japan. J. Struct. Geol. 48, 3-13.

Lin, A., Rao, G., Yan, B., 2014. Structural analysis of the right-lateral strike-slip Qingchuan fault, northeastern segment of the Longmen Shan thrust belt, central China. J. Struct. Geol. 68, 227-244.

Lin, A., Rao, G., Yan, B., 2015. Flexural fold structures and active faults in the northern-western Weihe Graben, central China. J. Asian. Earth Sci., this issue.

Lv, S., Li, Y., Wang, Y., Ci, H., 2014. The Holocene paleoseismicity of the North Zhongtiaoshan Faults in Shanxi Province, China. Tectonophysics 623, 67-82. 
374

375

Ma, X., Wu, D., 1987. Cenozoic extensional tectonics in China. Tectonophysics 133, 243-255.

McCalpin, J.P., 2009. Paleoseismology, Second edition. International geophysics series, vol. 95. Academic Press (613 pp).

Meghraoui, M., Delouis, B., Ferry, M., Giardini, D., Huggenberger, P., Spottke, I., Granet, M., 2001. Active normal faulting in the Upper Rhine graben and paleoseismic identification of the 1356 Basel earthquake. Science 293, 2070-2073.

Meng, Q., Zhang, G., 2000. Geologic framework and tectonic evolution of the Qinling orogen, central China. Tectonophysics 323, 183-196.

Obermeier, S.F., Dickenson, S.E., 2000. Liquefaction evidence for the strength of ground motions resulting from late Holocene Cascadia subduction earthquakes, with emphasis on the event of 1700 A.D. Bull. Seismol. Soc. Am. 90, 876-896.

Rao, G., Lin, A., Yan, B., Ren, Z., Jia, D., Wu, X., 2014. Tectonic activity and structural features of active intracontinental normal faults in the Weihe Graben, central China. Tectonophysics 638, 270-285.

Ratschbacher, L., Hacker, B., Calvert, A., Webb, L., Grimmer, J., McWilliams, M., Ireland, T., Dong, S., Hu, J., 2003. Tectonics of the Qinling (Central China): tectonostratigraphy, geochronology, and deformation history. Tectonophysics 366, $1-53$.

Shaanxi Earthquake Information Network (SEIN), 2011. Historical earthquakes in Shaanxi province (in Chinese). Available online at: http:// 

http://www.eqsn.gov.cn/manage/html/8abd83af1c88b3f2011c88b74299001f/sxls dz/index.html (Last accessed, 30 August 2014).

State Seismological Bureau (SSB), 1988. Active fault system around Ordos Massif (in Chinese). Seismological Press, Beijing, (352 pp.).

Stuiver, M., Reimer, P.J., Reimer, R., 2005. CALIB radiocarbon calibration version 7.0.http://radiocarbon.pa.qub.ac.uk/calib/ (Last accessed, 30 August 2014).

Wang, J., 1980. Ground ruptures during the large earthquake of 1556, Huaxian County, Shanxi. Acta Seismologica Sinica 2, 430-437 (in Chinese with English abstract).

Xie, Y., 1992. On magnitude of 1556 Guanzhong great earthquake. Journal of Catastrophology 7, 10-13 (in Chinese with English abstract).

Yeats, R., Seih, K., Allen, C., 1997. The Geology of earthquakes. Oxford University Press, Oxford (568 pp.).

Yin, G., Lu Y., Zhao, H., Li, W., Li, L., Guo, S., 2001. The tectonic uplift of the Hua Shan in the Cenozoic. Chin. Sci. Bull. 46, 1665-1668.

Yuan, T., Feng, X., 2010. The 1556 Huaxian great earthquake (in Chinese), Seismological Press, Beijing (386 pp.).

Zhang, A., Yang, Z., Zhong, J., Mi, F., 1995. Characteristics of late quaternary activity along the Southern Border Fault Zone of Weihe Graben Basin. Quatern. Int. 25, $25-31$.

Zhang, Y., Mercier, J.L., Vergély, P., 1998. Extension in the graben systems around the Ordos (China), and its contribution to the extrusion tectonics of south China with respect to Gobi-Mongolia. Tectonophysics 285, 41-75. 


\section{Figure captions}

Figure 1 (a) Geology of graben systems around the Ordos Block; (b) color-shaded relief map showing topographic features and the distribution of major active faults and historical earthquakes (modified from Deng, 2007); (c) geological map of the study area (modified from GBSP, 1999). The red star is the epicenter of the 1556 Huaxian great earthquake (CENC, 2007). ATF: Altyn Tagh Fault; HYF: Haiyuan Fault; KLF: Kunlun Fault; GZ-YSF: Ganzi-Yushu Fault; XSHF: Xianshuihe Fault; LMS: Longmenshan; NCB: North China Block; SCB: South China Block; QLF: Qinling Fault; HPF: Huashan Piedmont Fault; NMF-WLT: Northern Margin Fault of Weinan Loess Tableland; LPF: Lishan Piedmont Fault; KGF: Kouzhen-Guanshan Fault; WF: Weihe Fault.

Figure 2 (a) South-looking oblique 1-m IKONOS image of the Chishuihe region; (b) geological interpretation of the image; (c) topographic profiles across the fault scarp.

Figure 3 (a, b) Active faults displacing river banks (Locs. 1 and 2); (c) fault gouge; (d) striations observed along the main fault plane; (e) orientations of striations on the fault plane (lower hemisphere equal-arc stereographic projection), indicating normal-dominated slip.

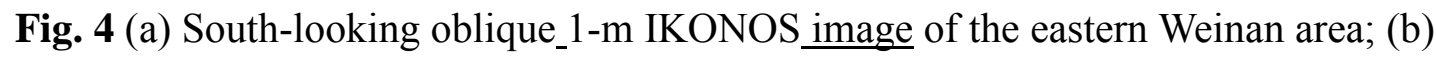
a 4.6-m-high fault scarp (Loc. 3); (c) ground fractures beneath the scarp; (d, e) striations on the sidewall indicating dip-slip motion.

Figure 5 (a, b) A 10-m-high fault scarp at Loc. 4; (c-e) tilted strata with internal 
bedding and a fault deformation zone composed of sub-parallel fault planes.

442

443

444

445

446

447

448

449

450

451

452

453

454

455

Figure 6 (a) Sketch of the outcrop at Loc. 4; (b, c) sand liquefaction; (d) grain-size distribution of boiled sands.

Figure 7 (a) Trench A, excavated across a 0.5-1.6-m-high fault scarp at Loc. 5; (b) ground fracture beneath the scarp; (c, d) striations on the sidewall indicate dip-slip motion.

Figure 8 (a) Photograph and (b) corresponding sketch of the east wall in Trench A.

Figure 9 (a) Photograph and (b) corresponding sketch of the west wall in Trench A.

Figure 10 Characteristic deformation and sedimentary features observed on the exposed walls in Trench A. (a) Colluvium; (b) fault plane displaced by injected colluvium; (c) injected veins; (d) cross-cutting veins.

Figure $11(a, b)$ Trench B, excavated across a 1.6-m-high fault scarp at Loc. 6; (c) overview of trench walls and exposed sedimentary layers.

Figure 12 (a) Photograph and (b) corresponding sketch of the west trench wall exposed in Trench B. 


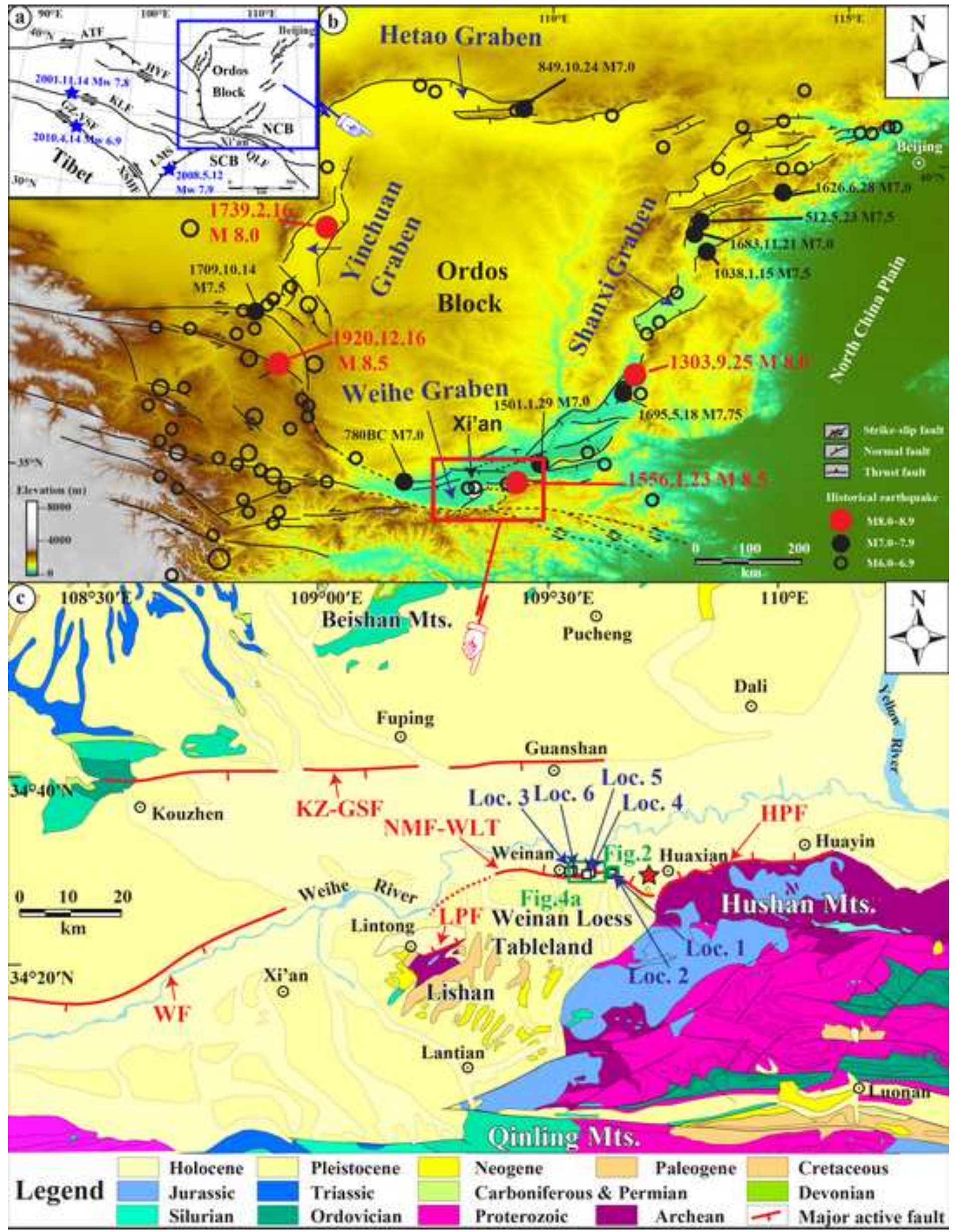




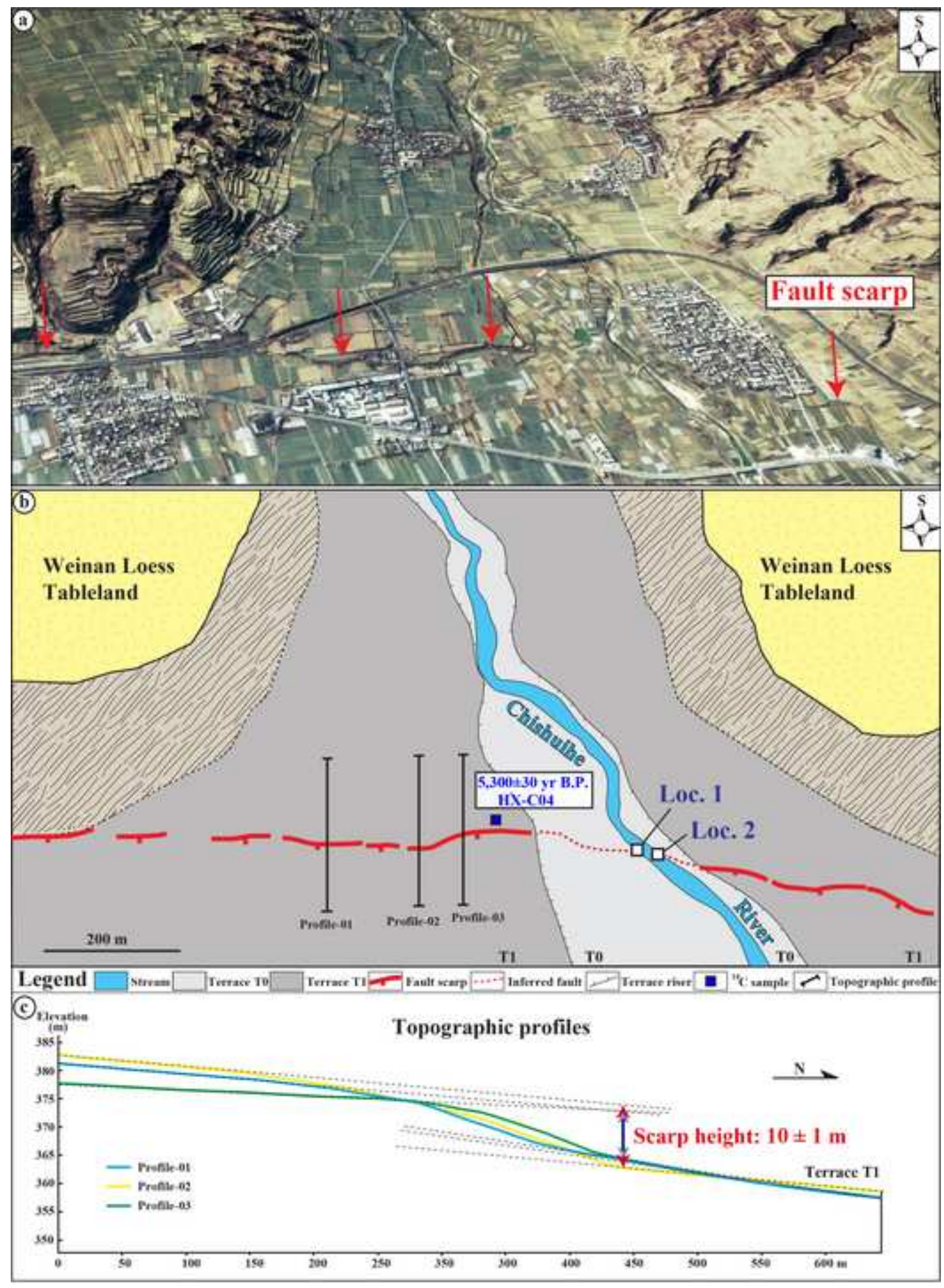

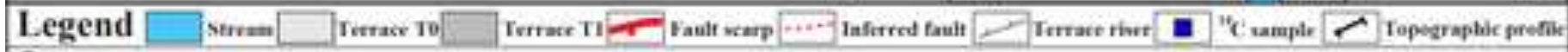
(c) niratien

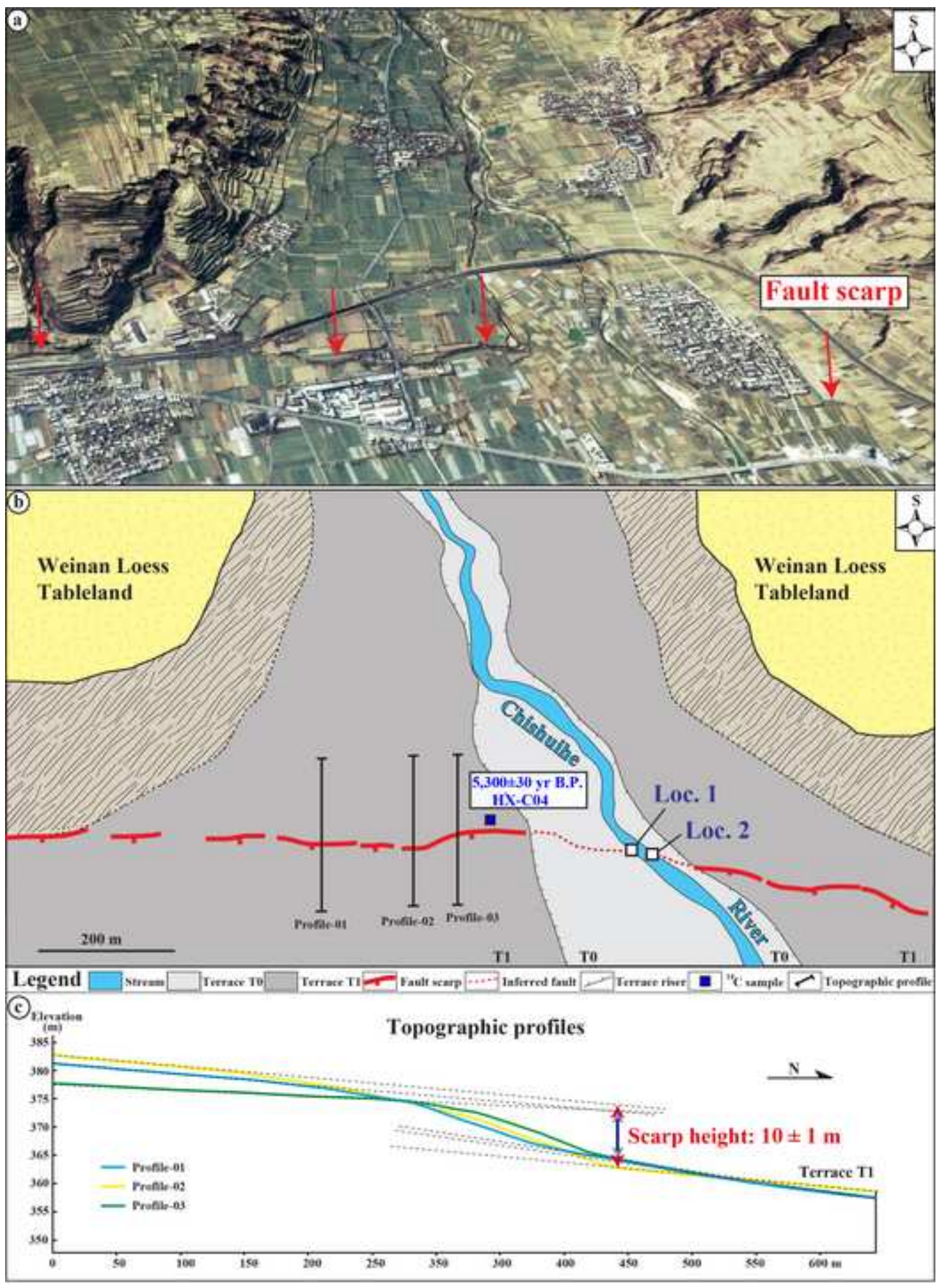

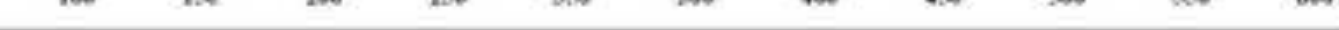


Click here to download high resolution image

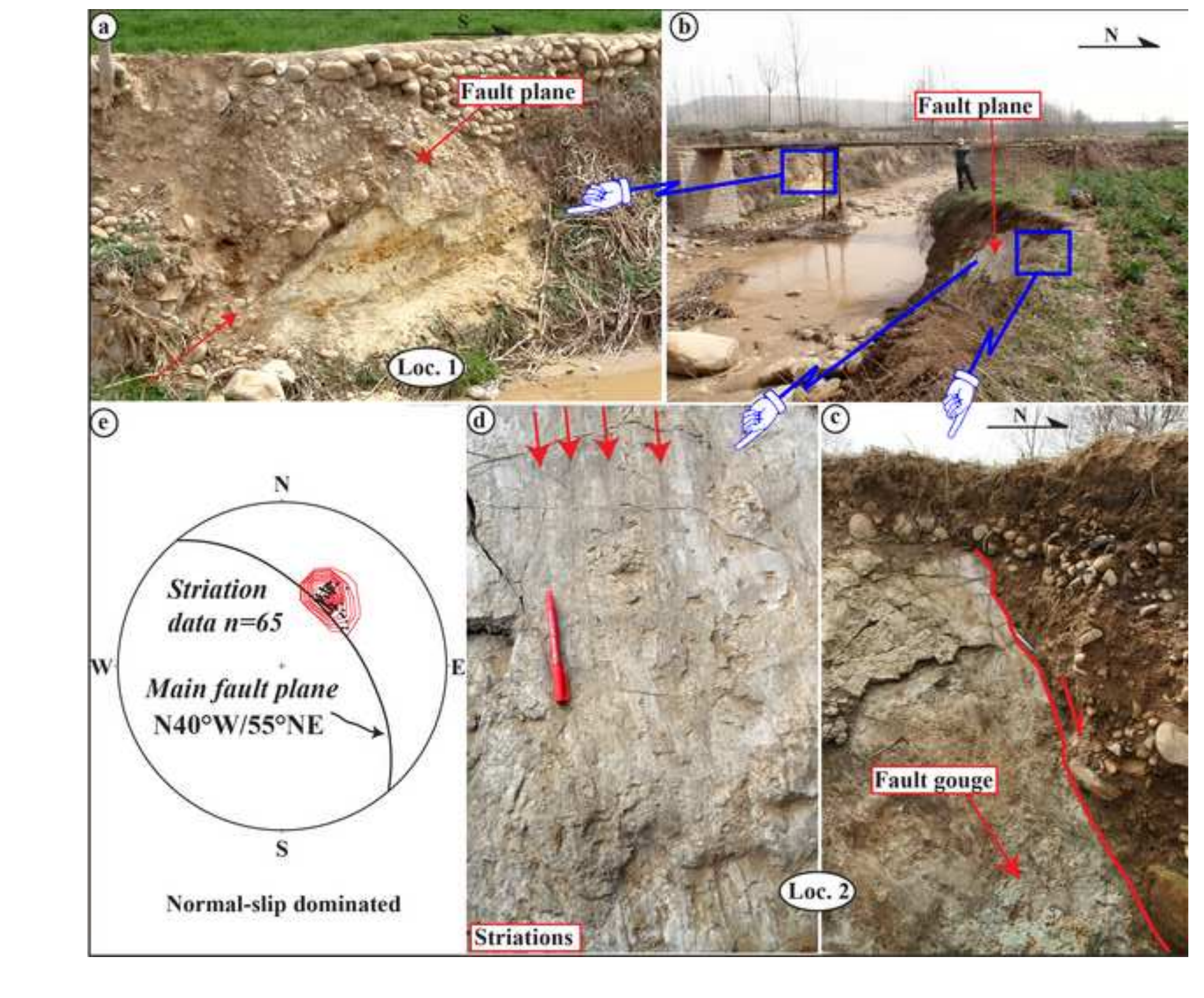

.

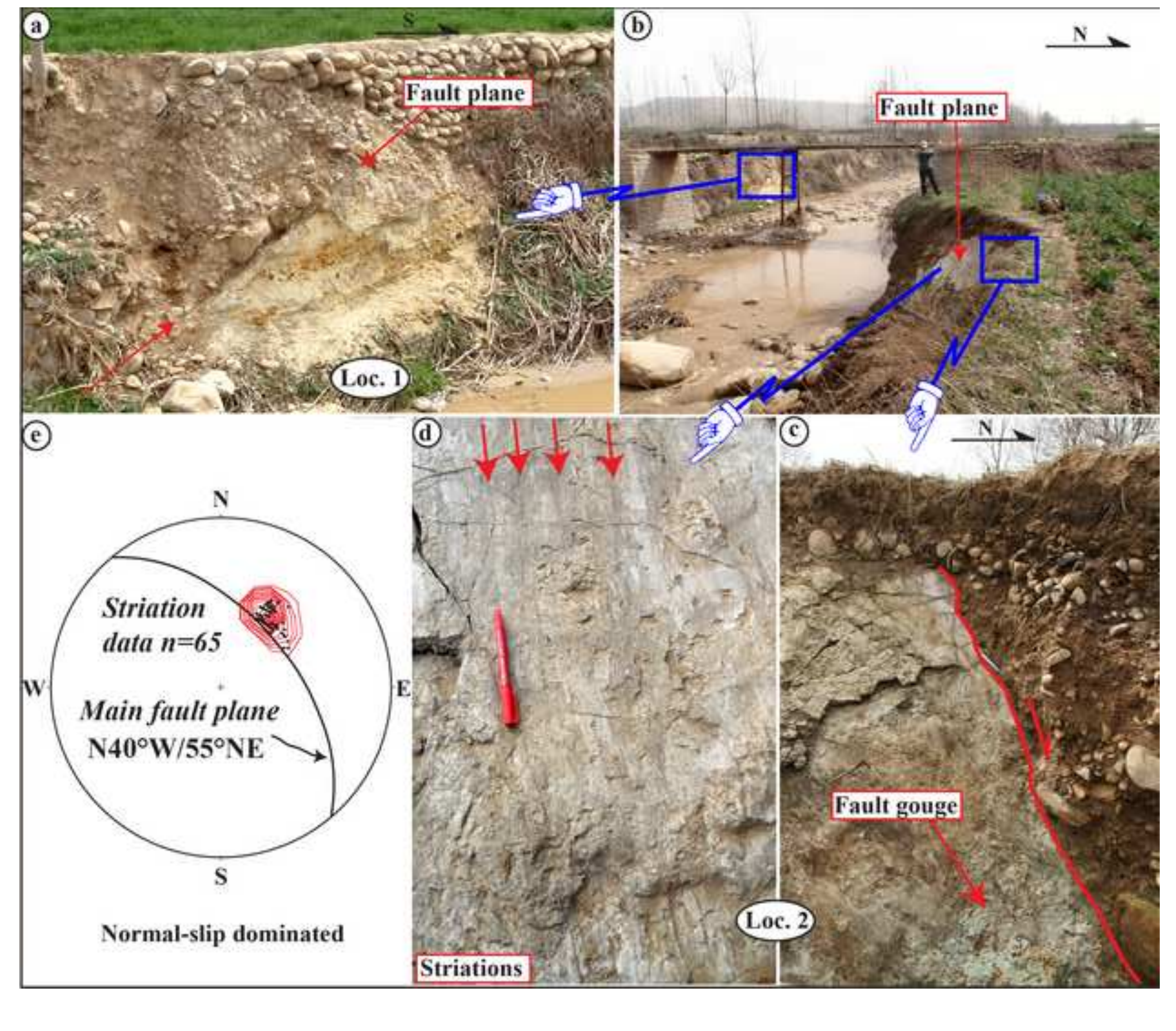




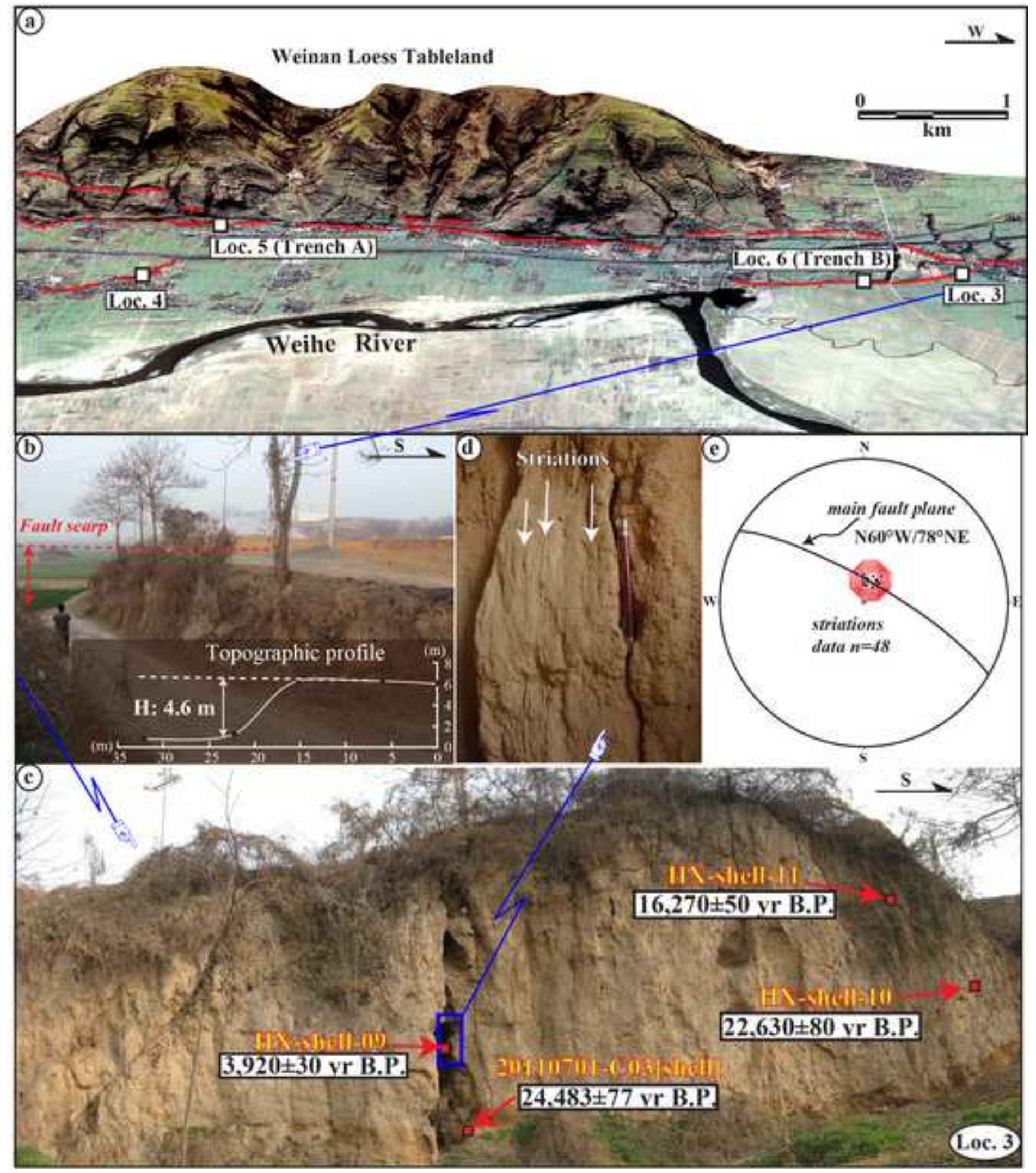




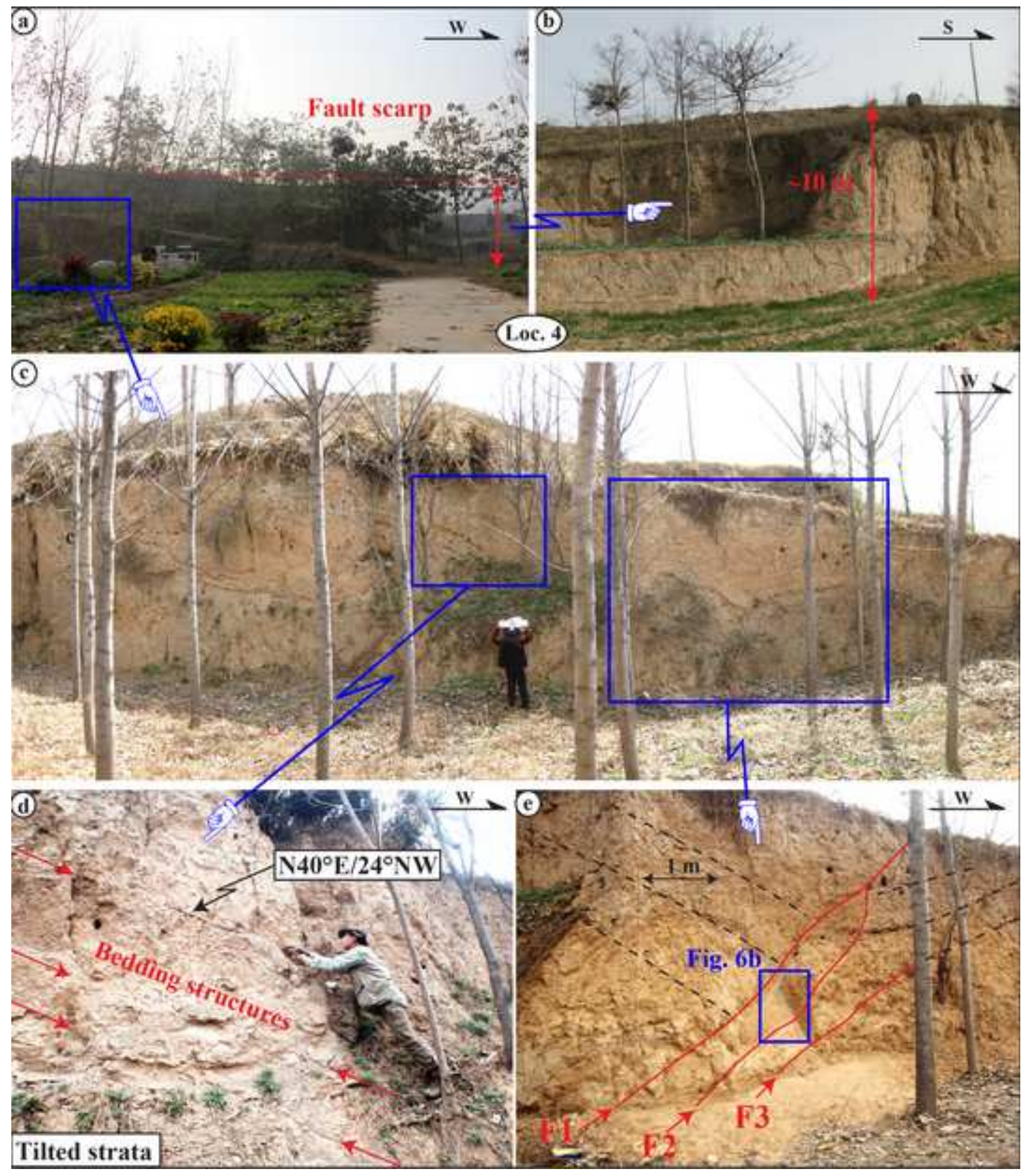




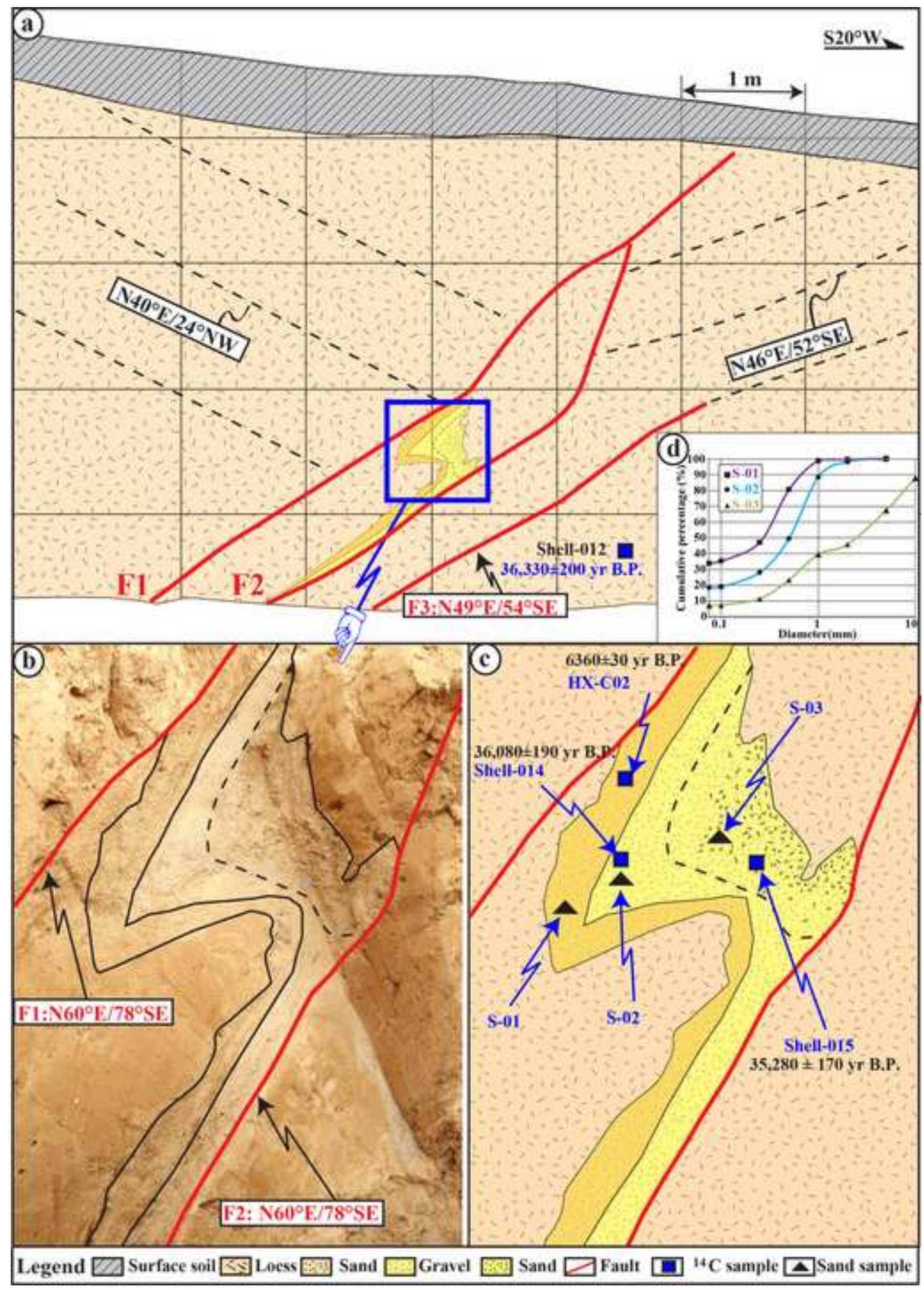

Legend $\square$ Surface soil $\square$ L Locss $\square$ Sand $\square$ Gravel $\square$ Sand $\square$ Fault $\square{ }^{14} \mathrm{C}$ sample $\square$ Sand sample 
Click here to download high resolution image

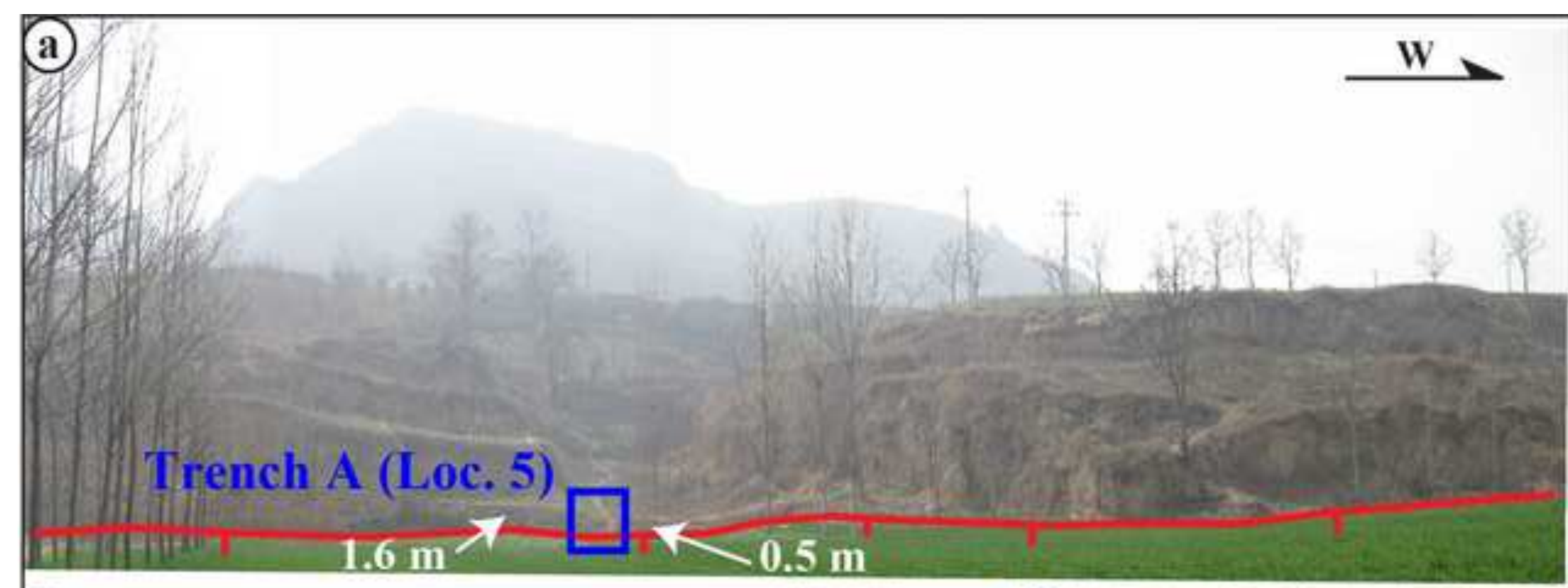

(b)

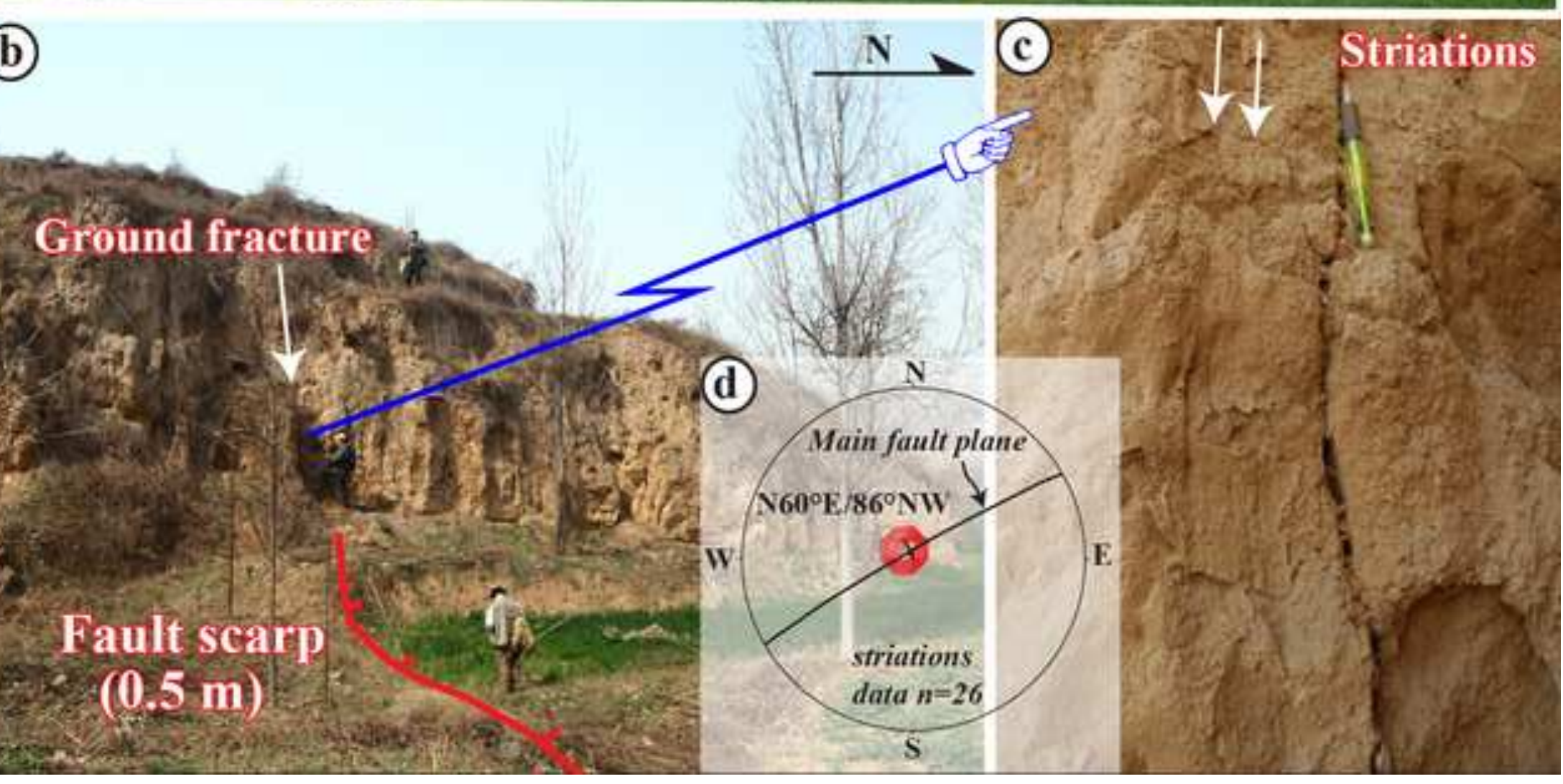




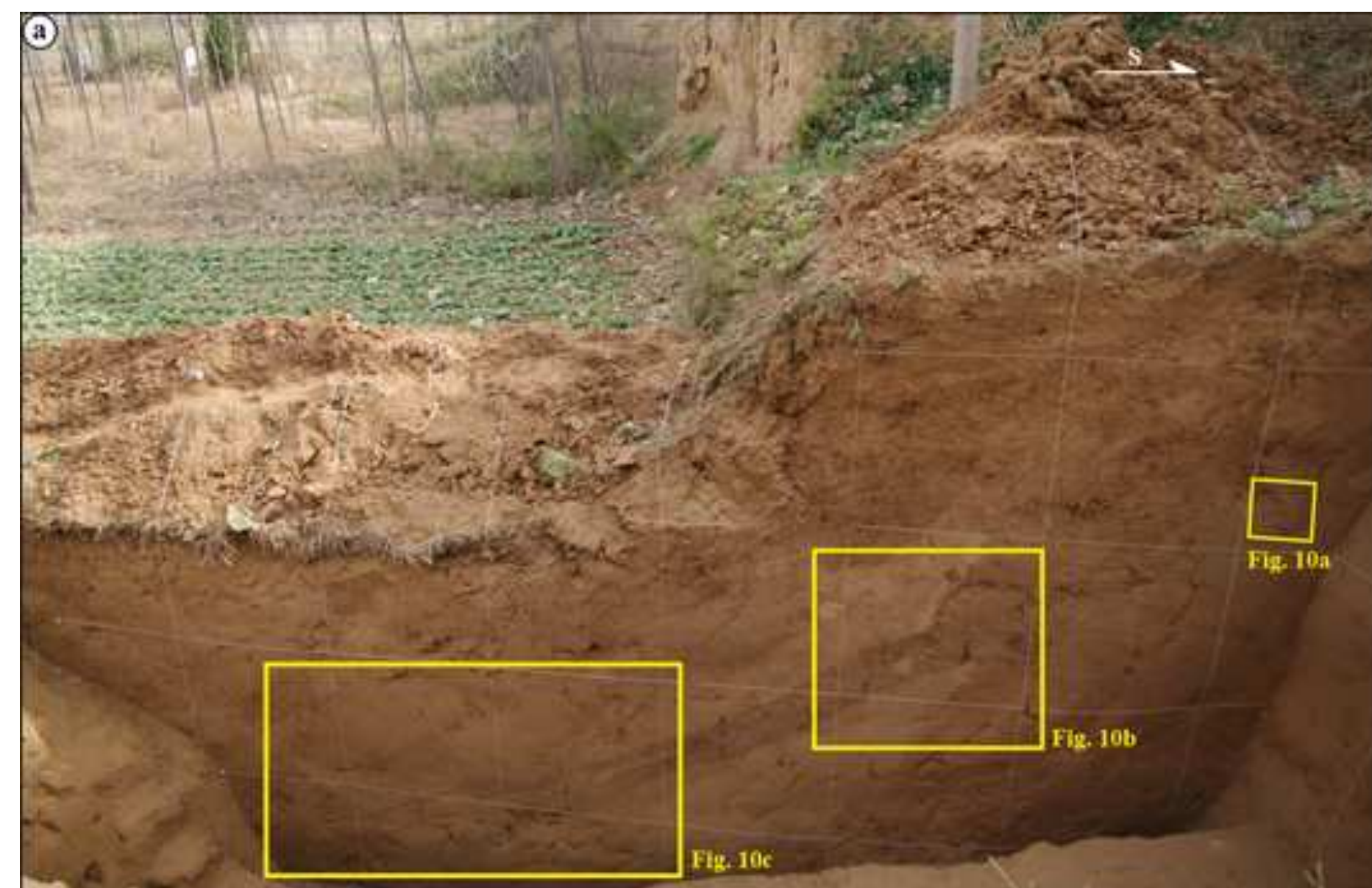

(b)

actist 20

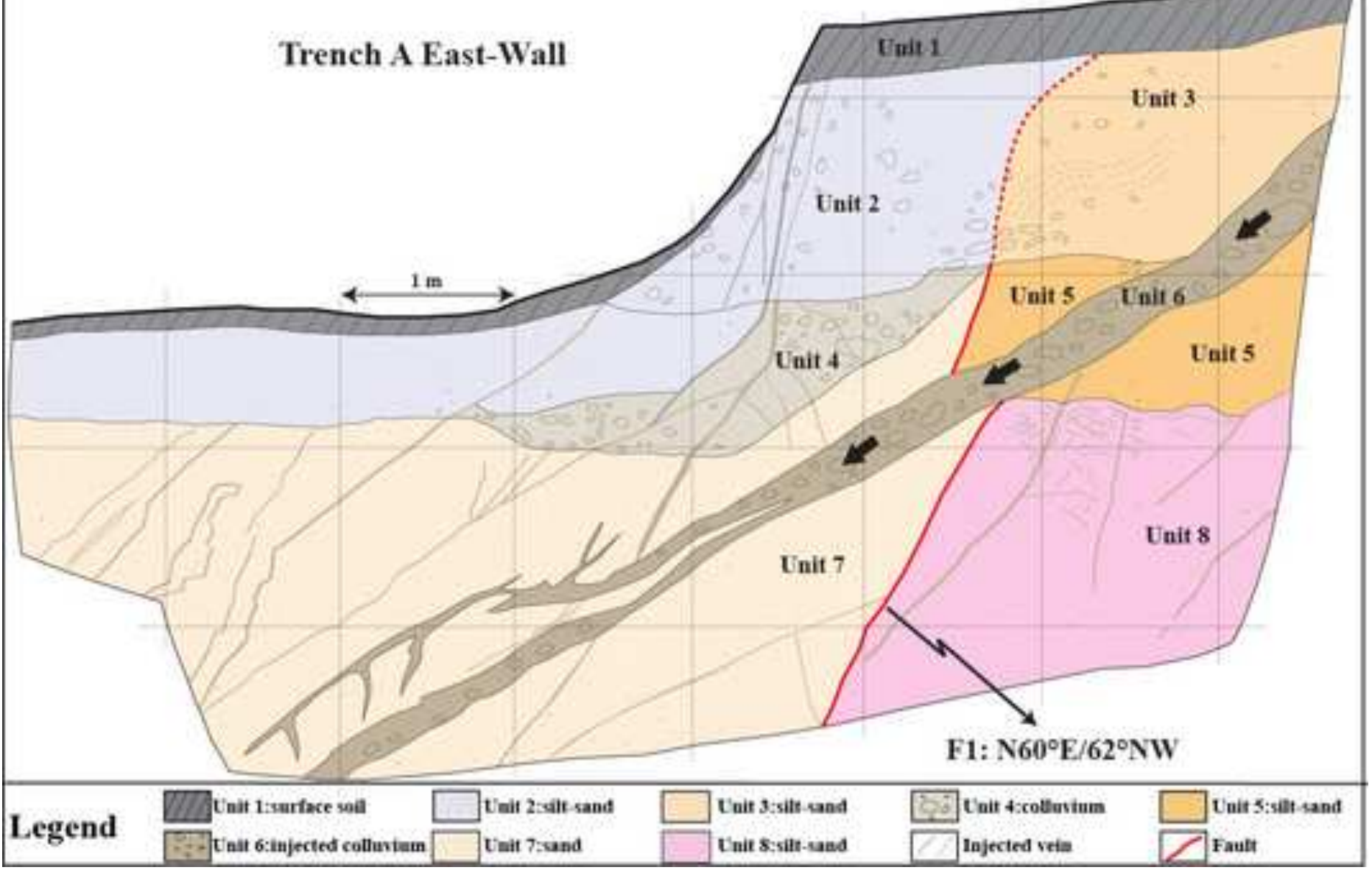


Click here to download high resolution image

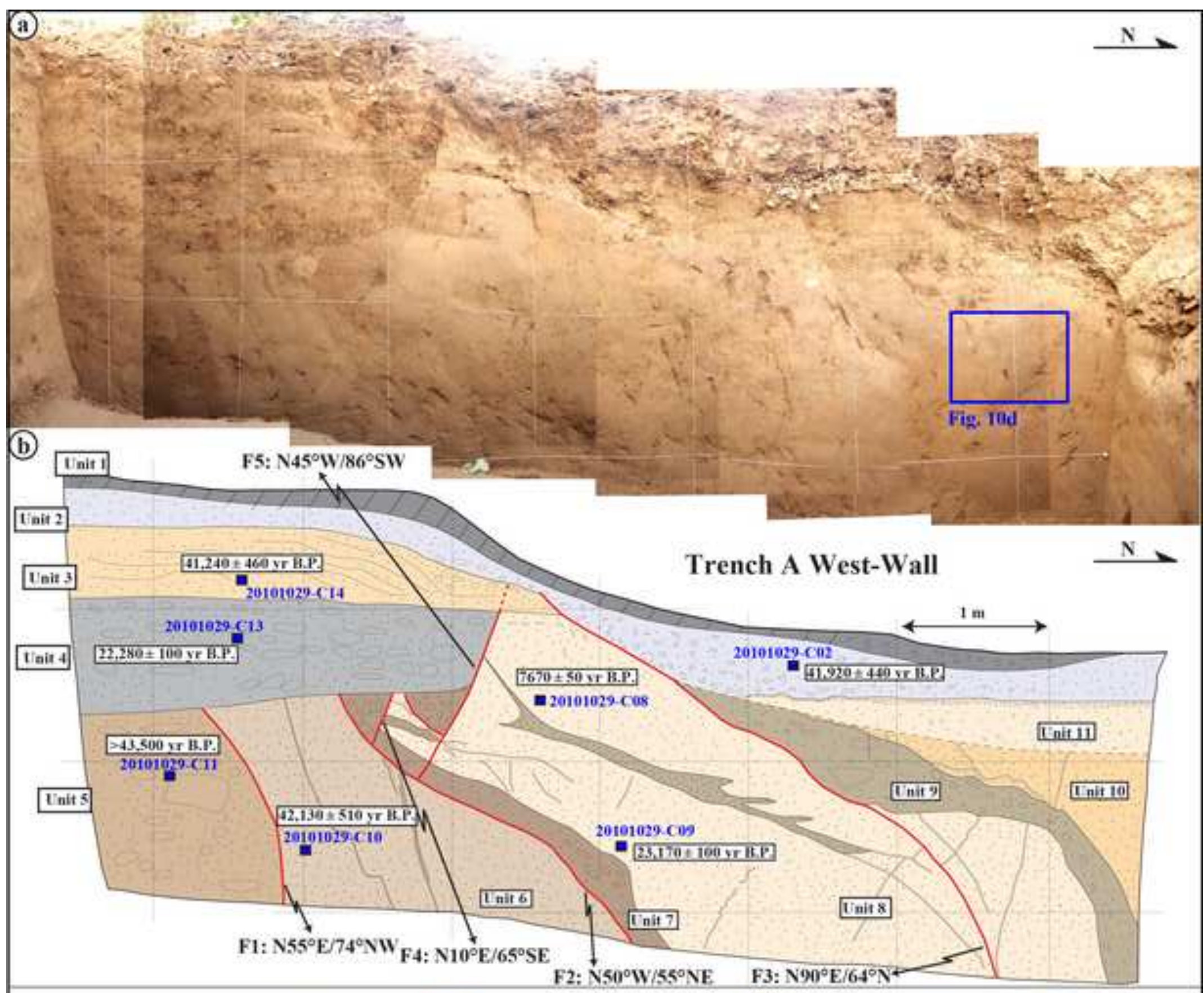

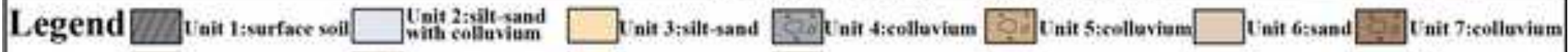

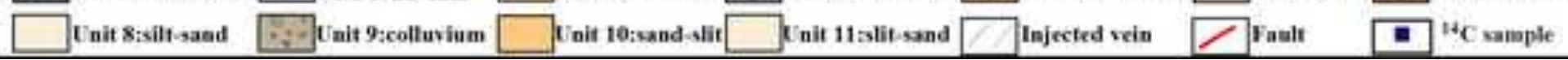



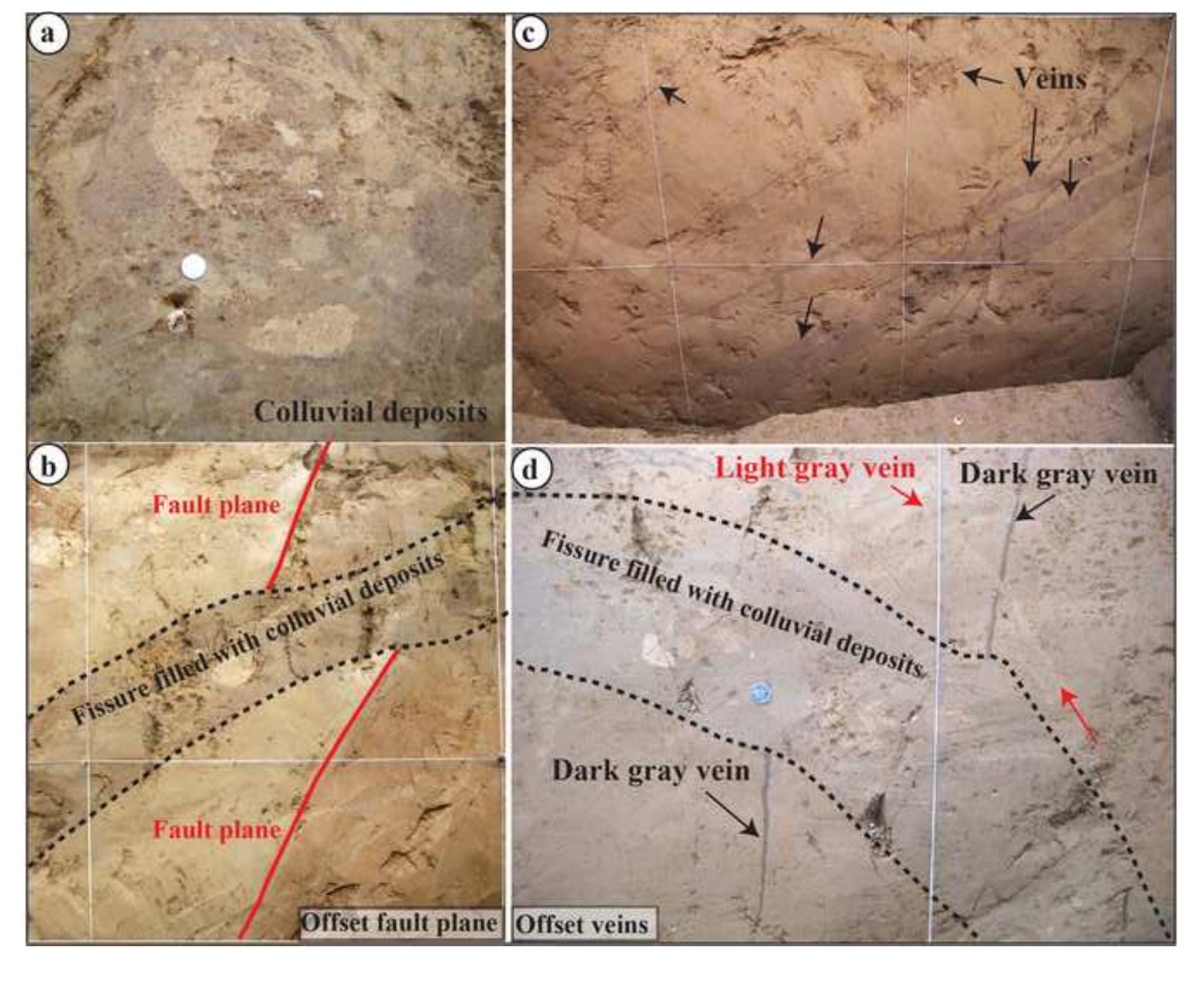

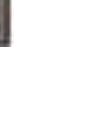


Click here to download high resolution image

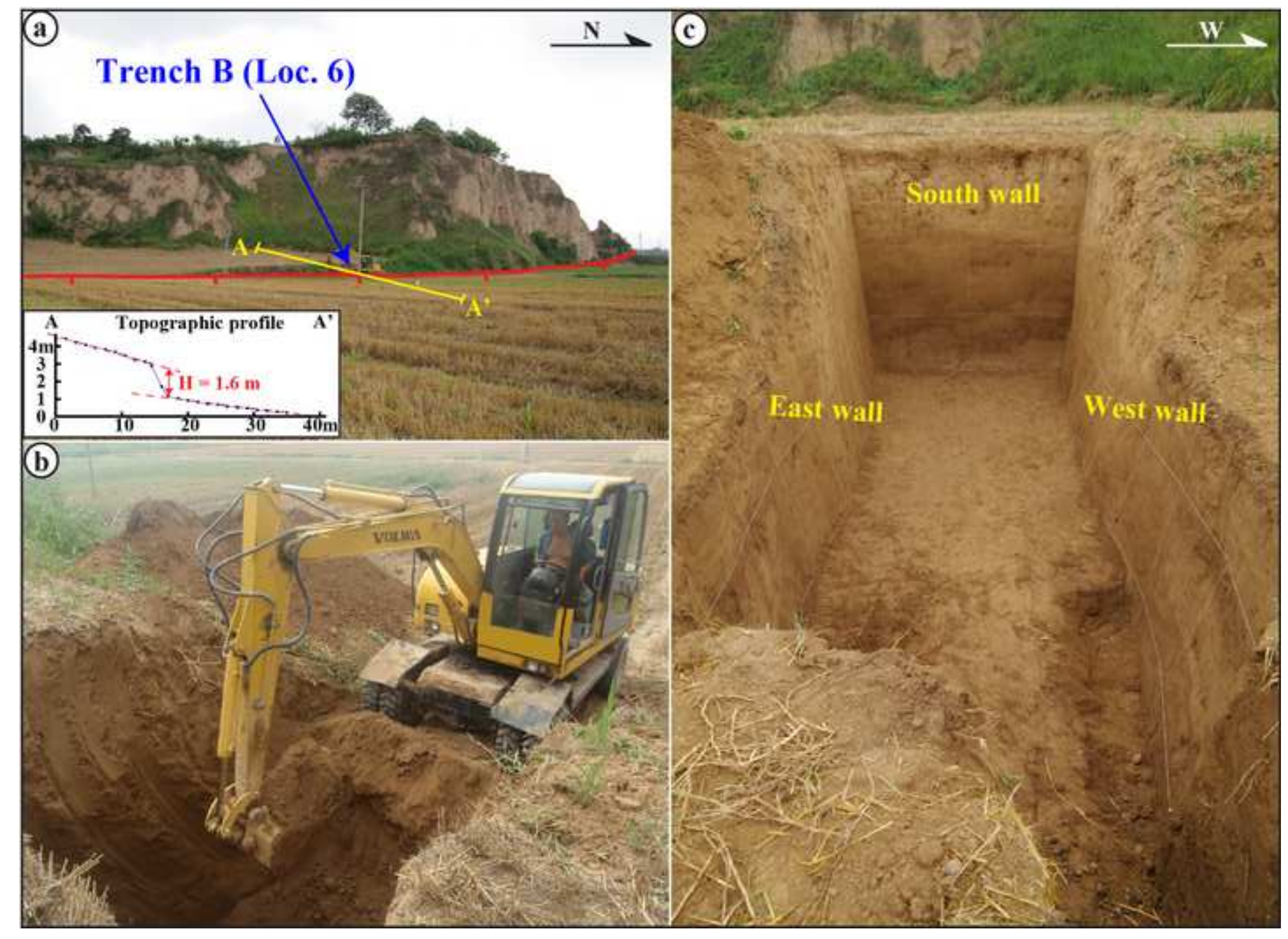




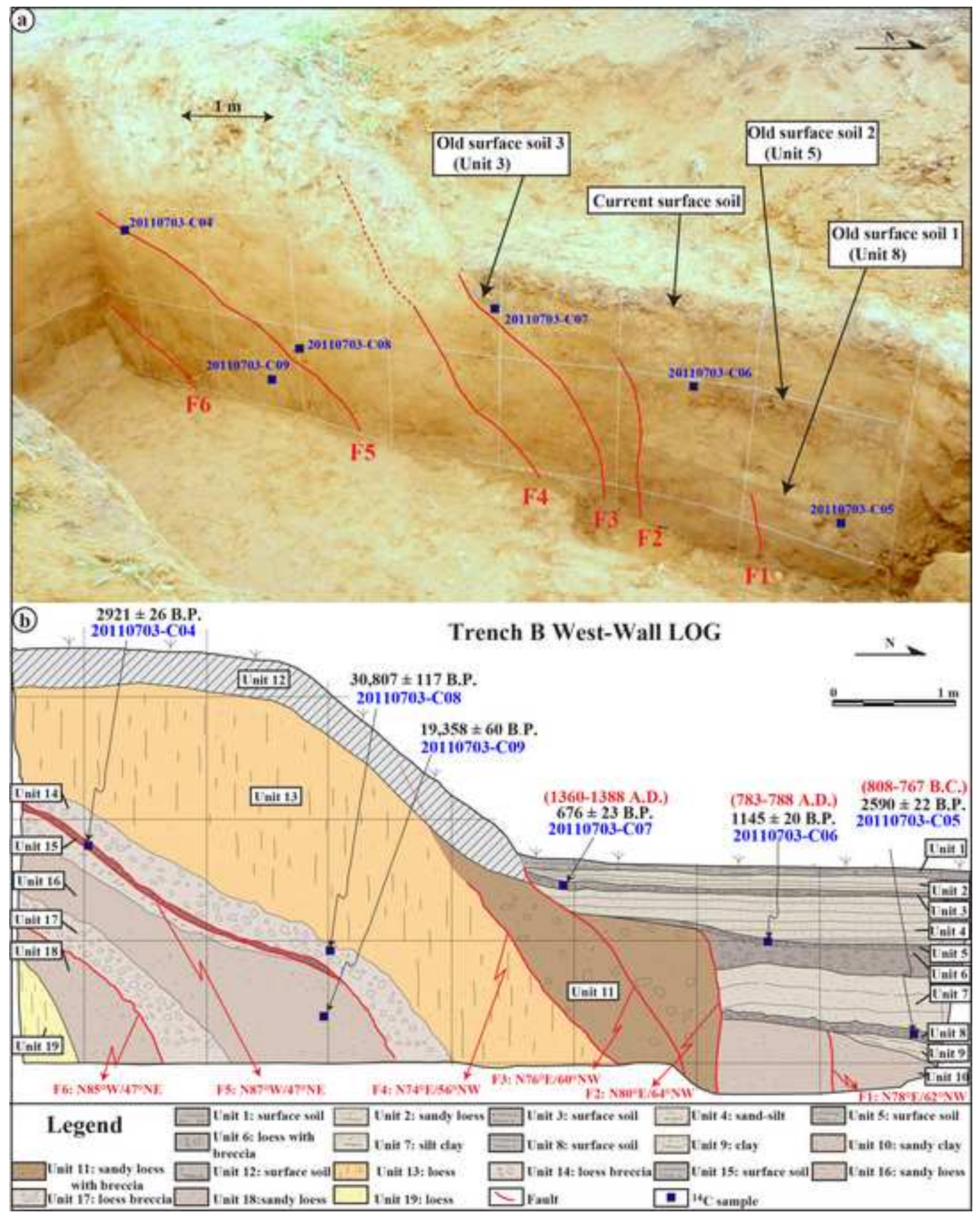


Table 1 Historical earthquakes of $M \geq 6$ in Weihe Graben.

\begin{tabular}{|l|l|c|l|}
\hline Date & Location & Magnitude & References \\
\hline AD 1568.7.5 & Xi'an & $\sim 6.75$ & EBASP, 1989; SEIN, 2011; \\
\hline AD 1556.1.23 & Huaxian & $\sim 8.5$ & $\begin{array}{l}\text { e.g. Kuo, 1957; Wang, 1980; SSB, 1988; Xie, } \\
\text { 1993; Zhang et al., 1995; Hou et al., 1998; } \\
\text { Yuan and Feng, 2010; }\end{array}$ \\
\hline AD 1501.1.19 & Chaoyi & $\sim 7$ & Wang, 1985; Wang et al., 2004; SEIN, 2011; \\
\hline AD 1487.8.10 & Lintong & $\sim 6.25$ & Wang, 1985, EBASP, 1989; \\
\hline AD 793.5.27 & Weinan & $\sim 6.5$ & Wang, 1985; EBASP, 1989; SEIN, 2011; \\
\hline BC 7.11.11 & $\begin{array}{l}\text { Northeast } \\
\text { to Xi'an (?) }\end{array}$ & $\sim 6$ & Wang, 1985; EBASP, 1989; \\
\hline BC 780 & $\begin{array}{l}\text { Qishan, } \\
\text { Huaxian (?) }\end{array}$ & $\sim 7$ & Wang, 1985; EBASP, 1989; SEIN, 2011. \\
\hline
\end{tabular}


Table 2 Radiocarbon age data for samples collected in Weihe Graben.

\begin{tabular}{|c|c|c|c|c|}
\hline Sample code & Laboratory ID & Radiocarbon age (yr B.P.) ${ }^{\dagger}$ & Calibrate age ( $2 \sigma$ uncertainties $)^{\ddagger}$ & Description $^{\S}$ \\
\hline $\mathrm{HX}-\mathrm{C} 02$ & IAAA-100062* & $6,360 \pm 30$ & \multirow{22}{*}{$\begin{array}{l}\text { 1213-1021 B.C. } \\
\text { 808-767 B.C. } \\
\text { 783-788 A.D. } \\
\text { 1360-1388 A.D. }\end{array}$} & ; Loc. 4; Fig. 6c. \\
\hline HX-Shell09 & IAAA-100063* & $3,920 \pm 30$ & & Shell; Loc. 3; Fig. 4c. \\
\hline HX-Shell10 & IAAA-100064* & $22,630 \pm 80$ & & Shell; Loc. 3; Fig. 4c. \\
\hline HX-Shell11 & IAAA-100065* & $16,270 \pm 50$ & & Shell; Loc. 3; Fig. 4c. \\
\hline HX-Shell12 & IAAA-100068* & $36,330 \pm 200$ & & ; Loc. 4; Fig. 6a. \\
\hline HX-Shell14 & IAAA-100070* & $36,080 \pm 190$ & & ; Loc. 4; Fig. 6c. \\
\hline HX-Shell15 & IAAA-100071* & $35,280 \pm 170$ & & ; Loc. 4; Fig. 6c. \\
\hline $\mathrm{HX}-\mathrm{C} 04$ & IAAA-100072* & $5,300 \pm 30$ & & Organic soil; Fig. 2 b. \\
\hline 20110701-C03 & IAAA-110681* & $24,483 \pm 77$ & & Shell; Loc. 3; Fig. 4c. \\
\hline 20110703-C04 & IAAA-110682* & $2,921 \pm 26$ & & Organic soil; Loc. 6; Fig. 12b. \\
\hline 20110703-C05 & IAAA-110683* & $2,590 \pm 22$ & & Organic soil; Loc. 6; Fig. 12b. \\
\hline 20110703-C06 & IAAA-110684* & $1,145 \pm 20$ & & Organic soil; Loc. 6; Fig. 12b \\
\hline 20110703-C07 & IAAA-110685* & $676 \pm 23$ & & Organic soil; Loc. 6; Fig. 12b \\
\hline 20110703-C08 & IAAA-110686* & $30,807 \pm 117$ & & Shell; Loc. 6; Fig. 12b. \\
\hline 20110703-C09 & IAAA-110687* & $19,358 \pm 60$ & & Shell; Loc. 6; Fig. 12b. \\
\hline 20101029-C02 & Beta-290414** & $41,920 \pm 440$ & & Shell; Loc. 5; Fig. 9b. \\
\hline 20101029-C08 & Beta-290415** & $7,670 \pm 50$ & & Organic soil; Loc. 5; Fig. 9b. \\
\hline 20101029-C09 & Beta-290416** & $23,170 \pm 100$ & & Shell; Loc. 5; Fig. 9b. \\
\hline 20101029-C10 & Beta-290417** & $42,130 \pm 510$ & & Shell; Loc. 5; Fig. 9b. \\
\hline 20101029-C11 & Beta-290418** & $>43,500$ & & Shell; Loc. 5; Fig. 9b. \\
\hline 20101029-C13 & Beta-290419** & $22,280 \pm 100$ & & Shell; Loc. 5; Fig. 9b. \\
\hline 20101029-C14 & Beta-290420** & $41,240 \pm 460$ & & Shell; Loc. 5; Fig. 9b. \\
\hline
\end{tabular}

"Samples were analyzed at the Institute of Accelerator Analysis Ltd., Japan; ${ }^{* *}$ Samples were analyzed at the BETA Analysis Inc., USA.

${ }^{\dagger}$ Using Accelerator Mass Spectrometry (AMS) method, referenced to the year 1950 A.D.

${ }^{\ddagger}$ Dendrochronologically calibrated calendar age by Method A from CALIB Radiocarbon Calibration Version 6.1 (Stuiver et al., 2005). 
${ }^{\S}$ Types of samples collected for ${ }^{14} \mathrm{C}$ age dating. 